\title{
MUTASI KLOROFIL TAHAP M2 PADI BERAS MERAH LOKAL SUMATERA BARAT GENOTIPE BANUHAMPU
}

\section{CHLOROPHIL MUTATIONS STAGE M2 RICE LOCAL RED RICE WEST SUMATERA GENOTYPE OF BANUHAMPU}

\author{
Deliana Andam Sari ${ }^{1 *}$, Irfan Suliansyah $^{2)}$, Indra Dwipa $^{3)}$ \\ 1) Politeknik Pertanian Negeri Payakumbuh, Kab. Limapuluh Kota, Indonesia \\ 2) Universitas Andalas, Padang, Indonesia \\ 3) Universitas Andalas, Padang, Indonesia \\ *penulis korespondensi \\ ${ }^{1)}$ delianaandamsari@gmail.com 2)irfansuliansyah@yahoo.com ${ }^{3)}$ 1965indradwipa@gmail.com
}

\begin{abstract}
Abstrak
Padi beras merah yang dibudidayakan di masyarakat Sumatera Barat saat ini merupakan padi lokal. Padi lokal memiliki keunggulan tertentu karena telah dibudidayakan secara turun-temurun sehingga telah beradaptasi dengan baik pada berbagai kondisi lahan dan iklim yang spesifik. Sebaliknya, padi lokal juga memiliki beberapa keterbatasan, antara lain berumur panjang, berpostur tinggi, tidak tahan hama dan penyakit, serta berproduksi rendah. Mutasi yaitu perubahan struktur genetik suatu makhluk hidup secara tiba- tiba dan acak yang diwariskan pada generasi berikutnya. Pemuliaan mutasi mempunyai karakter spesifik antara lain sangat efektif untuk merubah sedikit sifat dalam perbaikan varietas tanaman. Penelitian ini telah dilaksanakan pada bulan Agustus hingga Desember 2017. Pada saat persemaian dilakukan pengamatan mutasi klorofil untuk melihat adanya indikasi keragaman genetik akibat perlakuan iradiasi sinar gamma yang dilakukan terhadap benih. Setiap benih di persemaian diamati perubahan warna daunnya dan dikelompokkan kedalam kriteria Gustafsson. frekuensi mutan tertinggi adalah mutan dengan dosis $200 \mathrm{~Gy}$, sedangkan untuk frekuensi mutasi yang tertinggi adalah tanaman yang diiradiasi dengan dosis $300 \mathrm{~Gy}$. Tanaman yang diiradiasi dengan dosis $200 \mathrm{~Gy}$ memiliki frekuensi mutasi sebesar $0,09 \%$ dan untuk dosis 300 Gy frekuensi mutan yang terjadi adalah0,02\%.
\end{abstract}

Kata Kunci: genotipe banuhampu, mutasi klorofil, padi beras merah

\begin{abstract}
Brown rice that is cultivated in the people of West Sumatra is currently local rice. Local rice has certain advantages because it has been cultivated for generations so that it has adapted well to various specific land and climatic conditions. On the other hand, local rice also has several limitations, including long life, high posture, not resistant to pests and diseases, and low production. Mutation is a sudden and random change in the genetic structure of an organism that is passed on to the next generation. Mutation breeding has specific characteristics, among others, is very effective in changing a few traits in improving plant varieties. This research was conducted from August to December 2017. At the time of nursery, chlorophyll mutation was observed to see indications of genetic diversity due to gamma ray irradiation treatment carried out on the seeds. Each seed in the nursery was observed for changes in leaf color and grouped into Gustafsson's criteria. The highest mutant frequency was a mutant with a dose of 200 Gy, while the highest mutation frequency was a plant irradiated with a dose of $300 \mathrm{~Gy}$. Plants irradiated with a dose of $200 \mathrm{~Gy}$ had a mutation frequency of $0.09 \%$ and for a dose of $300 \mathrm{~Gy}$ the frequency of mutants was $0.02 \%$. while the highest frequency of mutations were plants irradiated with a dose of $300 \mathrm{~Gy}$. Plants irradiated with a dose of 200 Gy had a mutation frequency of $0.09 \%$ and for a dose of $300 \mathrm{~Gy}$ the frequency of mutants was $0.02 \%$. while the highest mutation frequency was the plants irradiated with a dose of $300 \mathrm{~Gy}$. Plants irradiated with a dose of $200 \mathrm{~Gy}$ had a mutation frequency of $0.09 \%$ and for a dose of 300 Gy the frequency of mutants was $0.02 \%$.
\end{abstract}

Keywords: banuhampu genotype, brown rice, chlorophyll mutation 


\section{Pendahuluan}

Beras merah sudah lama diketahui sangat bermanfaat bagi kesehatan, selain sebagai makanan pokok, antara lain untuk mencegah kekurangan pangan dan gizi serta menyembuhkan penyakit. Menurut (Sumartini, et al. 2018) beras merah mengandung gen yang memproduksi antosianin, antosianin yang dihasilkan merupakan sumber warna merah yang terdapat pada kondisi fisik beras,. Senyawa yang terdapat pada lapisan warna merah beras bermanfaat sebagai antioksidan, anti kanker, anti glikemik tinggi.

Perkembangan pengetahuan dan peningkatan taraf hidup masyarakat disertai kesadaran akan pentingnya kesehatan menyebabkan sebagian masyarakat mulai mengkonsumsi nasi beras merah. Hal ini karena nasi beras merah memiliki keistimewaan dan keunikan di dalam rasa maupun kandungan gizi atau vitamin. Beras merah juga kaya akan vitamin B dan E sehingga tidak mudah menimbulkan kembung saat dikonsumsi. Selain kandungan gizinya, keunggulan lain yang dimiliki beras merah adalah seratnya yang relatif lebih mudah dicerna dalam usus. Hal ini menyebabkan sisa-sisa makanan tidak tertahan terlalu lama di dalam usus sehingga usus belum sempat menyerap racun-racun yang ikut terbawa dalam makanan (Kristamini, 2009 ).

Padi beras merah yang dibudidayakan di masyarakat Sumatera Barat saat ini merupakan padi lokal. Menurut Suliansyah, et al (2016) padi lokal memiliki keunggulan tertentu karena telah dibudidayakan secara turun-temurun sehingga telah beradaptasi dengan baik pada berbagai kondisi lahan dan iklim yang spesifik. Sebaliknya, padi lokal juga memiliki beberapa keterbatasan, antara lain berumur panjang, berpostur tinggi, tidak tahan hama dan penyakit, serta berproduksi rendah.

Mutasi yaitu perubahan struktur genetik suatu makhluk hidup secara tiba- tiba dan acak yang diwariskan pada generasi berikutnya. Mutasi dapat terjadi secara spontan di alam (spontaneous mutation) dan dapat juga terjadi melalui induksi (induced mutation). Mutasi induksi dapat dilakukan melalui perlakuan mutagen pada materi genetik tanaman. Bagian tanaman yang diradiasi biasanya adalah benih yang akan ditumbuhkan atau bagian tanaman lainnya yang dapat ditumbuhkan. Karakter tanaman yang diamati dengan pemuliaan mutasi yaitu: ketahanan roboh, kemasakan tanaman, kebiasaan tumbuh dan tipe tanaman, ketahanan terhadap hama dan penyakit, daya hasil, dan kualitas. Pemuliaan mutasi mempunyai karakter spesifik antara lain sangat efektif untuk merubah sedikit sifat dalam perbaikan varietas tanaman. Mutasi genetik tanaman dapat diinduksi dengan menggunakan mutagen seperti iradiasi sinar gamma (Sobrizal, 2016). Adapun tujuan penelitian ini adalah mengetahui terjadinya mutasi klorofil atau tidak pada padi beras merah yang diberi perlakuan iradiasi sinar gamma.

\section{Metode Penelitian}

Penelitian ini telah dilaksanakan pada bulan Agustus hingga Desember 2017. Tempat penelitian dilaksanakan di sawah irigasi Jorong Labuah, Nagari Sungai Batang, Kecamatan Tanjung Raya, Kabupaten Agam yang memiliki ketinggian $\pm 500 \mathrm{mdpl}$.

Pelaksanaan penelitian yaitu benih hasil panen dari tahap M1 akan disemai di persemaian kering. Benih yang digunakan yaitu benih hasil iradiasi dengan dosis 200 Gy dan 300 Gy genotipe 
Вапиһатри. Pada saat persemaian dilakukan pengamatan mutasi klorofil untuk melihat adanya indikasi keragaman genetik akibat perlakuan iradiasi sinar gamma yang dilakukan terhadap benih. Setiap benih di persemaian diamati perubahan warna daunnya dan dikelompokkan kedalam kriteria Gustafsson. Benih dipindahkan ke sawah saat umur 3 minggu setelah semai. Jumlah benih yang ditanam di sawah setiap galurnya yaitu 100 benih. Penanaman dilakukan satu batang pada satu lubang tanam. Penelitian dilakukan dalam bentuk seleksi dan data ditampilkan dalam bentuk deskriptif.

\section{Hasil dan Pembahasan}

Mutasi klorofil merupakan indikasi terjadinya keragaman genetik pada tanaman M2 (Sobrizal, 2008). Dwipa, et al (2018) berpendapat mutasi klorofil pada tanaman padi dapat diamati secara visual di persemaian. Pengamatan mutasi klorofil dilakukan saat tanaman berumur 1 minggu hingga 3 minggu setelah semai dengan melihat perubahan warna daun pada setiap individu tanaman di persemaian. Pengamatan mutasi klorofil berdasarkan metode Gustarfsson. Gustafsson mengenalkan penamaan macam-macam perubahan warna daun akibat mutasi klorofil, penamaan berdasarkan hasil penelitian mutasi klorofil pada tanaman Barley. Mutasi klorofil yang dikemukakan Gustafsson dapat diamati pada kecambah tanaman M2 serelia (monokotil).

Dari hasil penelitian ini diperoleh beberapa tipe mutasi klorofil yang terjadi pada tahap M2 yang muncul diantaranya yaitu tipe Albina, Clorina, Virecen, Striata, Tigrina, dan Marginata.Tipe mutasi klorofil yang terjadi akan terlihat pada Gambar 1.

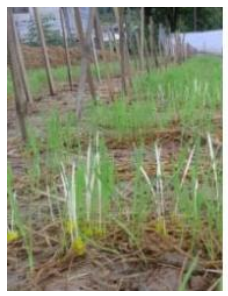

Albina

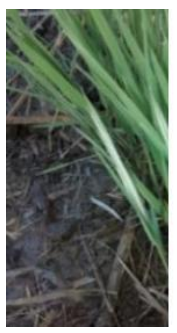

Striata

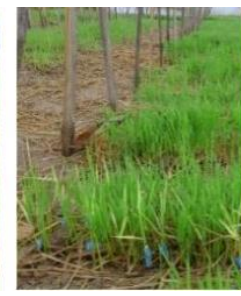

Clorina

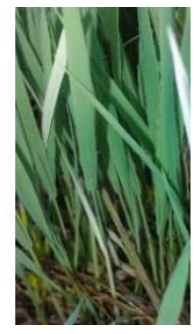

Tigrina

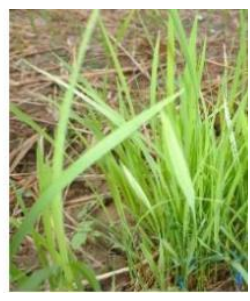

Virecen

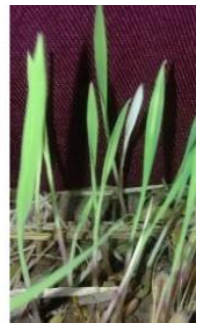

Marginata

Gambar 1. Tipe mutasi klorofil

Sumber: dokumen pribadi

Dari hasil pengamatan di lapangan mutasi klorofil tipe albina terlhat seluruh daun berwarna putih. Tipe albina tidak dapat tumbuh selanjutnya akan mati, hal ini karena tanaman tidak memiliki kandungan klorofil. Tipe mutasi klorofil selanjutnya yaitu clorina dicirikan dengan penampakan pada daun berwarna kuning. Sedangkan pada mutasi klorofil virescen dicirikan dengan warna daun hijau dan terdapat warna kekuningan di tulang daun. Mutasi klorofil 
tipe Striata dicirikan dengan daun berwarna putih dan terdapat strip hijau pada bagian kiri dan kanan tepi daun. Mutasi klorofil yang ditemukan selanjutnya yaitu tipe tigrina dan marginata. 3 minggu setelah persemaian perubahan warna pada mutan selain tipe mutan albina warna daun akan berubah menjadi warna hijau.

Tipe mutasi klorofil, frekuensi mutan, frekuensi mutasi pada saat penanaman tahap M2 padi beras merah genotipe Banuhampu dapat dilihat pada Tabel 1.

Tabel 1. Hasil mutasi klorofil berdasarkan dosis iradiasi sinar gamma

\begin{tabular}{|c|c|c|c|c|c|c|c|c|c|c|c|}
\hline \multirow{2}{*}{$\begin{array}{l}\text { Dosis } \\
\text { mutasi }\end{array}$} & \multicolumn{6}{|c|}{ Tipe Mutasi Klorofil } & \multirow[t]{2}{*}{ Mutan } & \multirow{2}{*}{$\begin{array}{l}\text { Jumlah } \\
\text { Populasi }\end{array}$} & \multirow{2}{*}{$\begin{array}{l}\text { Total } \\
\text { Mutasi }\end{array}$} & \multirow{2}{*}{$\begin{array}{l}\text { Jumlah } \\
\text { Mutan }\end{array}$} & \multirow{2}{*}{$\begin{array}{l}\text { Frek. } \\
\text { Mutasi }\end{array}$} \\
\hline & alb & clo & mar & stri & vire & tigrina & & & & & \\
\hline 200 gry & 167 & 34 & 21 & 1 & 1 & 5 & 229 & 39600 & 34 & $0.58 \%$ & $0.09 \%$ \\
\hline frek.mutan & 0.729 & 0.148 & 0.092 & 0.004 & 0.004 & 0.022 & & & & & \\
\hline 300 gry & 273 & 8 & 12 & 14 & 0 & 1 & 308 & 24000 & 4 & $1.28 \%$ & $0.02 \%$ \\
\hline frek.mutan & 0.886 & 0.026 & 0.039 & 0.045 & 0 & 0.003 & & & & & \\
\hline Kontrol & - & - & - & - & - & - & - & - & - & - & - \\
\hline
\end{tabular}

Dari data Tabel 1 terlihat bahwa frekuensi mutan tertinggi adalah mutan dengan dosis 200 Gy, sedangkan untuk frekuensi mutasi yang tertinggi adalah tanaman yang diiradiasi dengan dosis $300 \mathrm{~Gy}$. Tanaman yang diiradiasi dengan dosis 200 Gy memiliki frekuensi mutasi sebesar 0,09\% dan untuk dosis 300 Gy frekuensi mutan yang terjadi adalah0,02\%. Apabila dilihat berdasarkan tipe mutasi klorofil yang terjadi diketahui bahwa frekuensi mutan tertinggi adalah tipe mutasi klorofil albina pada dosis iradiasi 300 Gy. Frekuensi mutan tipe albina pada dosis 200 Gy yaitu 0,7 \% dan pada dosis 300 Gy 0,8\%.frekuensi mutan terendah yaitu tipe mutasi klorofil viresen, tipe ini pada dosis iridiasi 200 Gy hanya 0,004 sedangkan pada dosis iridiasi 300 Gy tidak ditemukan tipe mutasi klorofil ini.

Frekuensi mutasi yang diperoleh pada iridiasi sinar gamma pada padi beras merah genotype Banuhampu ini tidak setinggi hasil yang diperoleh dari penelitian yang dilaporkan oleh Dwipa et.al (2018) terhadap padi beras merah genotipe Sigah yang di iridiasi dengan sinar gamma, frekuensi mutan tertinggi adalah mutan dengan dosis $200 \mathrm{~Gy}$, sedangkan untuk frekuensi mutasi yang tertinggi adalah tanaman yang diiradiasi dengan dosis 300 Gy. Tanaman yang diiradiasi dengan dosis 200 Gy memiliki frekuensi mutan sebesar 1,28\% dan untuk dosis 300 Gy frekuensi mutan yang terjadi adalah 1,00\%. Menurut Ismachin (2007) mutasi klorofil mudah diamati karena terlihat oleh mata secara langsung. Nilahayati et al. (2016) berpendapat mutasi klorofil sering digunakan untuk mengevaluasi pengaruh genetik dari berbagai mutagen.

\section{Kesimpulan}

Pengamatan mutasi klorofil dilakukan saat tanaman berumur 1 minggu hingga 3 minggu setelah semai dengan melihat perubahan warna daun pada setiap individu tanaman di persemaian. Mutasi klorofil tipe albino terlhat seluruh daun berwarna putih. Tipe albino tidak dapat tumbuh selanjutnya akan mati, hal ini karena tanaman tidak memiliki kandungan klorofil. Frekuensi mutan tertinggi adalah mutan dengan dosis $200 \mathrm{~Gy}$, sedangkan untuk frekuensi mutasi yang tertinggi adalah tanaman yang diiradiasi dengan dosis $300 \mathrm{~Gy}$. Tanaman yang diiradiasi 
dengan dosis 200 Gy memiliki frekuensi mutasi sebesar 0,09\% dan untuk dosis 300 Gy frekuensi mutan yang terjadi adalah0,02\%. Mutasi klorofil sering digunakan untuk mengevaluasi pengaruh genetik dari berbagai mutagen.

\section{Daftar Pustaka}

Dwipa, I., Irfan S., Deliana A.S., 2018. Studi seleksi mutan berumur genjah padi beras merah lokal sumatera barat pada tahap M2. Prosiding Seminar Nasional Perhimpunan Ilmu Pemuliaan Indonesia (PERIPI). Padang. Hal 10-18

Ismachin, M. 2007. Perkembangan pemuliaan mutasi di indonesia. Diklat Pemuliaan Mutasi. FPAI BATAN. Jakarta. $18 \mathrm{Hal}$

Kristamtini, 2009. Respon tiga padi merah lokal DIY terhadap pupuk cair semi organik. Jurnal Agrosains Balai Pengkajian Teknologi Pertanian. Yogyakarta Karangsari, Wedomartani, Ngemplak, Sleman. Vol. 11.Hal 1-6

Nilahayati, Rosmayati, Diana S.H., Fauziyah H., 2016. Tipe dan jumlah mutan pada generasi M1 kedelai kipas putih hasil iradiasi sinar gamma. Prosiding Seminar Nasional BKS PTN Wilayah Barat Bidang Ilmu Pertanian 2016, Lhokseumawe

Sobrizal. 2008. Pemuliaan mutasi dalam peningkatan manfaat galur-galur terseleksi asal persilangan antar subspesies padi. A Scientific Journal for The Applications of Isotopes and Radiation Vol. 4. Hal 23-36

Sobrizal. 2016. Potensi Pemuliaan Mutasi untuk Perbaikan Varietas Padi Lokal Indonesia. Jurnal Ilmiah Aplikasi Isotop dan Radiasi Vol. 12 No. 1. Hal 23-35.4

Suliansyah, I., Indra D., Yusniwati. 2016. Pengembangan Padi Beras Merah Local Sumatera Barat: Eksplorasi dan Karakterisasi. Prosiding Seminar dan Lokakarya Nasional Agroteknologi/Agroekoteknologi.Sumartini, Hasnelly, Sarah, 2018. Kajian peningkatan kualitas beras merah ( Oryza Nivara ) instan dengan cara fisik. Pasundan food technology journal, Volume 5, no 1. Hal 84-90. 